\title{
Volcanic caves: priorities for conserving the Azorean endemic troglobiont species
}

Paulo A.V. Borges 1,2,3*, Pedro Cardoso ${ }^{1,4,5}$, Isabel R. Amorim ${ }^{1,2}$, Fernando Pereira ${ }^{1,2,3}$, João P. Constância ${ }^{2,3}$, João C. Nunes ${ }^{2,3,6}$, Paulo Barcelos ${ }^{2,3}$, Paulino Costa ${ }^{2,3,7}$, Rosalina Gabriel $^{1}$, and Maria de Lurdes Dapkevicius ${ }^{8}$

\begin{abstract}
:
Borges P.A.V., Cardoso P., Amorim I.R., Pereira F., Constância J.P., Nunes J.C., Barcelos P., Costa P., Gabriel R. and Dapkevicius M.d.L. 2012. Volcanic caves: priorities for conserving the Azorean endemic troglobiont species. International Journal of Speleology, 41(1), 101-112. Tampa, FL (USA). ISSN 0392-6672. DOI: http://dx.doi.org/10.5038/1827-806X.41.1.11

Azorean lava-tubes and volcanic pits adequately sampled for arthropod fauna were evaluated for species diversity and rarity. An iterative partial multiple regression analysis was performed to produce a multi-criteria index (Importance Value for Cave Conservation, IV-CC) incorporating arthropod species diversity indices but also including indices qualifying cave geological and management features (e.g., the diversity of geological structures, threats, accessibility). Additionally, we calculated complementarity solutions (irreplaceability and Fraction-of-Spare measures) for each cave with different targets per species, i.e., the minimum number of caves needed for each species to be represented either once or twice. Our results clearly show that to preserve all troglobiont arthropods endemic to the Azores, it is crucial to protect several caves per island. As many as 10 and 15 caves are needed to include one or two occurrences, respectively, per species.
\end{abstract}

Keywords: multi-criteria index; complementarity; irreplaceability; fraction-of-spare; conservation; Azorean lava-tubes

Received 1 November 2011; Revised 18 December 2011; Accepted 21 December 2011

\section{INTRODUCTION}

Obligate cave-adapted terrestrial species (troglobionts sensu Sket, 2008) tend to exhibit a high degree of endemism, occurring in only one or very few sites (caves) (Barr \& Holsinger, 1985; Christman et al., 2005; Culver \& Pipan, 2009). This characteristic is particularly important in oceanic archipelagos, in which most troglobionts occur on only one island and

${ }^{1}$ Universidade dos Açores, Dep. Ciências Agrárias, Grupo da Biodiversidade dos Açores (CITA-A), 9700-042 Angra do Heroísmo, Terceira, Açores; (pborges@uac.pt)

2“Os Montanheiros”, Rua da Rocha, 9700 Angra do Heroísmo, Terceira, Açores, Portugal

${ }^{3}$ GESPEA (Grupo para o Estudo do Património Espeleológico dos Açores) Portugal

${ }^{4}$ Associação dos Espeleólogos de Sintra - FPE, Sintra, Portugal

${ }^{5}$ Núcleo de Espeleologia da Costa Azul - FPE, Sesimbra, Portugal ${ }^{6}$ Universidade dos Açores, Departamento de Geociências Apartado 1422, 9500-801 Ponta Delgada, Portugal

${ }^{7}$ Secretaria Regional do Ambiente e do Mar - Rua Cônsul Dabney, Colónia Alemã, Apartado 140, 9900-014 Horta, Portugal

${ }^{8}$ Universidade dos Açores, Dep. Ciências Agrárias, Grupo da Tecnologia Alimentar (CITA-A), 9700-042 Angra do Heroísmo, Terceira, Açores, Portugal are thus Single-Island Endemics (SIEs). Thus, caveadapted species could be considered very restricted in distribution due to their low dispersal abilities and cave isolation (Christman \& Culver, 2001). Cave arthropod diversity can be correlated with habitat availability, i.e., the number of caves, at both local and regional scales (Christman \& Culver, 2001) and with the area of the caves (Silva et al., 2011). Moreover, due to the small range size of troglobiont species, alpha local diversity is usually small and partly explained by regional factors (Christman \& Culver, 2001; Christman et al., 2005; Malard et al., 2009). Although the area of a cave has been some times correlated with cave diversity (e.g. Silva et al., 2011), the local-regional species richness relationship (i.e., proportional sampling model vs. local saturation model sensu Ricklefs, 1987) has not been formally examined for terrestrial subterranean fauna. Malard et al. (2009) showed that the species richness of stygobionts (aquatic cave-obligate species) in karstic local communities increased linearly with regional richness, whereas that of porous local communities reached an asymptote beyond a certain value of regional richness.

The Macaronesian islands (Azores, Madeira, Selvagens, Canaries, Cape Verde) are of volcanic origin and have hundreds of volcanic caves (i.e., lava- 
tubes and volcanic pits) (Borges \& Oromí, 1994; Oromí \& Izquierdo, 1994). Many species of troglobionts have been described over the past decades for the Macaronesian archipelagos of Madeira (Serrano \& Borges, 2010), the Azores (Borges \& Oromi, 1994) and the Canaries (Oromi \& Martín, 1992; Oromi \& Izquierdo, 1994; Oromí, 2004). In the latter two archipelagos, troglobionts represent an important fraction of the unique endemic fauna of the islands (Oromí \& Izquierdo, 1994; Oromí, 2004).

In this work, we focus on the arthropod caveadapted fauna of the Azores. This fauna is in urgent need of conservation because most caves are located in highly disturbed areas, the result of almost 600 years of anthropogenic disturbance and land-use changes in the archipelago (Borges et al., 2009). Because conservation resources are limited, it is impossible to protect all caves inhabited by troglobionts in the Azores. To establish a sound conservation plan, conservation priorities must be set for Azorean caves (Borges et al., 2008). Endangered cave arthropods in the Azores, as elsewhere, are often not considered in national or international conservation policies (Amorim, 2005; Whitten, 2009; Cardoso, 2011; Cardoso et al., 2011a, b). An exception to this lack of attention is the recent list of the top 100 management priority species for the European archipelagos of the Macaronesian region
(Martín et al., 2010), which includes several caveadapted species. However, many cave arthropods are not included in the abovementioned list, namely, species exclusive to caves that are outside officially protected areas. As troglobionts are often the only representatives of a particular trophic guild in a cave, the "health" of a cave ecosystem relies heavily on their existence (Culver \& Pipan, 2009).

In a preliminary assessment, Borges et al. (2008) showed that a small number of Azorean volcanic caves are irreplaceable and need to be preserved to protect the current species richness of Azorean troglobionts. Irreplaceability in a conservation planning exercise was originally defined by Pressey et al. (1994) as the frequency of selection of a given site by possible alternative solutions that reach the defined conservation targets. However, as recognized by those authors, this definition had the problem of redundancy. Even sites that were not crucial for achieving the target would be assigned a certain irreplaceability value. Ferrier et al. (2000) then refined the measure by defining irreplaceability as the frequency at which a given site would need to be selected (i.e., would be crucial) in possible alternative solutions to ensure that the conservation targets are achieved. Fraction-of-Spare is a newly developed conservation measure (Phillips et al., 2010) that,

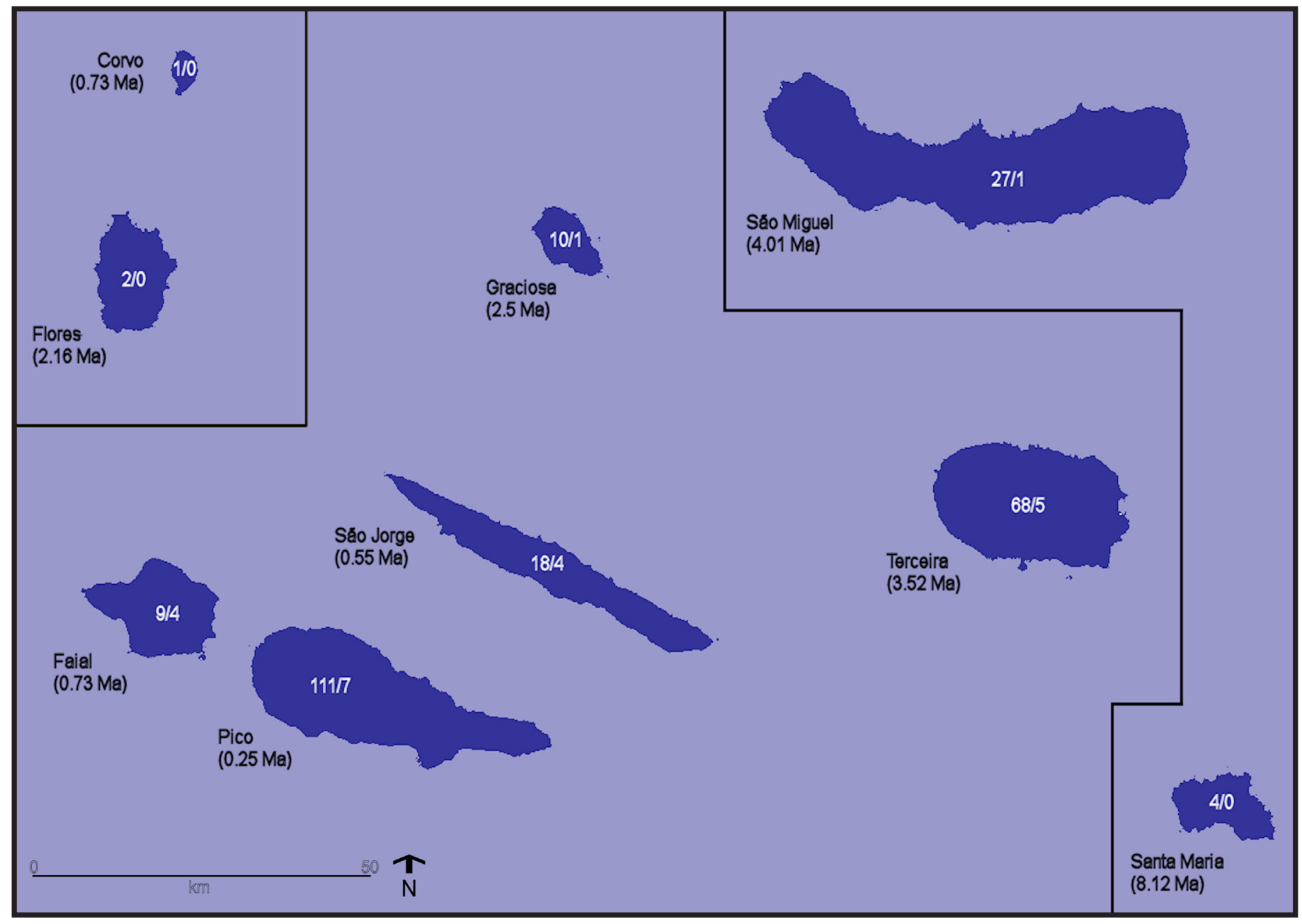

Fig. 1. The Azorean islands, showing the maximum subaerial age in millions of years (Ma) (Nunes, 1999), the number of caves (left of slash) and the number of troglobiont species (right of slash). The Western, Central and Eastern island groups are drawn within separate boxes in the figure and are not shown in their true geographical positions. 
like irreplaceability, represents the importance of a site in reaching defined targets or, conversely, specifies the proportion of the available options for reaching the targets that would be lost if a given site was excluded from selection for conservation. The purposes of irreplaceability and Fraction-of-Spare are similar. However, under certain circumstances the Fraction-of-Spare measure may offer advantages that irreplaceability does not provide (see Phillips et al., 2010).

We use data obtained in standardized studies (same sampling effort to all caves) performed during the past two years (2009-2010) to examine the relative value of a set of well-sampled lava tubes and volcanic pits to improve the conservation of the biodiversity of Azorean cave-adapted arthropods. The objectives of this paper are: (i) to test the effectiveness of two widespread ecological patterns, the speciesarea curve and the relationship between local and regional species richness, in explaining the local diversity of troglobiont species; (ii) to rank caves using a set of criteria such as arthropod diversityand rarity-based indices as well as cave geological and management features; and (iii) to calculate the irreplaceability and Fraction-of-Spare measures for each cave with different targets per species, i.e., the minimum number of caves needed for each species to be represented either once or twice.

\section{MATERIALS AND METHODS}

\section{Sites and data}

This study was conducted in the Azores, a volcanic Northern Atlantic archipelago that comprises nine islands distributed from northwest to southeast, roughly between $37^{\circ}$ and $40^{\circ} \mathrm{N}$ and $24^{\circ}$ and $31^{\circ} \mathrm{W}$. The Azorean islands extend for approximately $615 \mathrm{~km}$ and are situated across the Mid-Atlantic Ridge, which separates the western island group (Flores and Corvo) from the central (Faial, Pico, São Jorge, Terceira and Graciosa) and the eastern (São Miguel and Santa Maria) groups (Figure 1). All islands are relatively recent, ranging from 8.12 Myr B.P. (S. Maria) to 250,000 years B.P. (Pico) (Nunes, 1999).

As the result of several recent lava flows in the Azores, many lava-tubes and volcanic pits occur on the islands. A total of 250 cavities were recently listed in a database of the Azorean caves (Pereira et al., in prep.): 163 lava-tubes, 37 pits, 12 pit-caves and 38 cavities of other types (e.g., cavities formed by erosion, artificial caves).

In this study, a total of 42 volcanic cavities (37 lava-tubes and 5 volcanic pits) on six of the nine Azorean islands (excluding S. Maria, Flores and Corvo) were surveyed and are listed (see Table 1). A number of those caves were surveyed intensively during 1988 and 1990 by two expeditions sponsored by the National Geographic Society under the supervision of Pedro Oromí (Univ. de La Laguna, Spain) and Philippe Ashmole (Univ. of Edinburgh, UK) (see Oromi et al., 1990). However, many of the caves were also sampled by researchers at the University of the Azores and "Os Montanheiros" (see Borges \&
Table 1. Ranking of 42 Azorean volcanic caves based on the multicriteria index Importance Value for Cave Conservation (IV-CC). Caves with IV-CC above the mean value $(0.477)$ are shown in bold.

\begin{tabular}{|l|l|l|}
\hline Cave & Island & IV-CC \\
\hline Furna dos Montanheiros & Pico & $\mathbf{0 . 6 8 3}$ \\
\hline Gruta de Água de Pau & São Miguel & $\mathbf{0 . 6 8 2}$ \\
\hline Algar do Morro Pelado & São Jorge & $\mathbf{0 . 5 9 4}$ \\
\hline Gruta do Chocolate & Terceira & $\mathbf{0 . 5 8 2}$ \\
\hline Gruta das Agulhas & Terceira & $\mathbf{0 . 5 8 2}$ \\
\hline Gruta dos Balcões & Terceira & $\mathbf{0 . 5 6 3}$ \\
\hline Gruta do Soldão & Pico & $\mathbf{0 . 5 6 2}$ \\
\hline Algar das Bocas do Fogo & São Jorge & $\mathbf{0 . 5 5 7}$ \\
\hline Gruta do Henrique Maciel & Pico & $\mathbf{0 . 5 4 9}$ \\
\hline Furna das Cabras II (terra) & Pico & $\mathbf{0 . 5 3 9}$ \\
\hline Algar do Carvão & Terceira & $\mathbf{0 . 5 3 0}$ \\
\hline Gruta da Ribeira do Fundo & Pico & $\mathbf{0 . 5 2 7}$ \\
\hline Gruta do Coelho & Terceira & $\mathbf{0 . 4 9 1}$ \\
\hline Gruta de Santa Maria & Terceira & $\mathbf{0 . 4 8 9}$ \\
\hline Gruta da Branca Opala & Terceira & $\mathbf{0 . 4 8 5}$ \\
\hline Furna Nova I & Pico & $\mathbf{0 . 4 8 2}$ \\
\hline Gruta da Malha & Terceira & $\mathbf{0 . 4 7 8}$ \\
\hline Gruta das Torres & Pico & 0.469 \\
\hline Furna do Enxofre & Graciosa & 0.468 \\
\hline Gruta da Achada & Terceira & 0.468 \\
\hline Gruta do Pico da Cruz & São Miguel & 0.467 \\
\hline Gruta do Carvão & São Miguel & 0.460 \\
\hline Furna de Frei Matias & Pico & 0.458 \\
\hline Gruta da Agostinha & Pico & 0.455 \\
\hline Gruta da Madre de Deus & Terceira & 0.454 \\
\hline Gruta do Mistério da Silveira I & Pico & 0.453 \\
\hline Gruta do Pico Queimado & São Miguel & 0.453 \\
\hline Gruta das Canárias & Pico & 0.447 \\
\hline Gruta das Anelares & Faial & 0.447 \\
\hline Gruta do Natal & Terceira & 0.444 \\
\hline Gruta do Caldeira & Terceira & 0.439 \\
\hline Gruta da Beira & São Jorge & 0.437 \\
\hline Gruta do Cabeço do Canto & 0.380 \\
\hline Furna da Baliza & 0.371 \\
\hline Gruta dos Principiantes & 0.367 \\
\hline Gruta do Enforcado & 0.359 \\
\hline Gruta dos Buracos & 0.401 \\
\hline Gruta do Esqueleto & 0.396 \\
\hline Gruta dos Vimes & & 0.392 \\
\hline Furna Ruim do Forninho & Tara \\
\hline
\end{tabular}


Oromí, 1994) and in more recent studies (e.g., Borges et al., 2004, 2007; Amorim, 2005). The cave arthropod presence/absence data are in part unpublished and resulted from recent surveys performed by Isabel Amorim and Fernando Pereira (2009 and 2010) and by Paulo Borges and Fernando Pereira within the FCT project PTDC/AMB/70801/2006 - Understanding Underground Biodiversity: Studies of Azorean Lava Tubes (2009-2011). In this study we only include caves which were subject to comparable standardized protocols: all caves were surveyed using baited pitfalls and also standardized time search methods covering the deep zone of complete darkness, the transition zone of near-complete darkness, the twilight zone near the cave entrance and the cave entrances (see more details in Oromí et al., 1990).

\section{Data analysis}

Based on the recent Borges et al. (2010) list of Azorean arthropods, the species were classified in one of three colonization categories: endemics (species occurring only in the Azores, as a result of either speciation events (neo-endemics) or extinction of the mainland populations (palaeo-endemics)), natives (i.e. species which arrived by long-distance dispersal in the Azores and which also occur in other archipelagos and/or on continents) and introduced (i.e. species believed to occur in the archipelago as a result of human activities; some of these species have a worldwide distribution). In doubtful cases, a species was assumed to be native. Moreover, based on the species traits cited in Borges \& Oromi (1994) and Reboleira et al. (2011), the species were also classified as follows (Sket, 2008): troglobionts - species adapted to the cave environment and generally unable to survive in epigean environments; eutroglophiles - species that can spend their entire lives in caves but occur in other environments; subtroglophiles - species that use caves but cannot complete their life cycle in caves; and trogloxenes - species occurring sporadically in caves and unable to establish a subterranean population. In the current paper, we use primarily the troglobiont and eutroglophile Azorean endemic species for further analyses.

Ordinary regression methods were used to relate species diversity to cave length (a surrogate of true cave area) and local (cave) and regional (island) species richness. Local species richness was calculated as the mean number of species per cave in a particular island and regional species richness is the total number of species known from each island (see Srivastava, 1999).

To prioritize the 42 volcanic caves, two techniques were used: i) indices for scoring conservation priorities based on comparative analyses; and ii) methods based on the complementarity of sites and their contribution toward given targets.

\section{Scoring method}

Due to its simplicity, a scoring approach involving a multi-criteria index based on nine different indicators was used. This approach incorporated biological information and also included cave geological and management features. The partial indicators corresponding to the selected biological characteristics included the following measures: the species richness of troglobiont arthropods (Strogl), selected because reflects the presence of unique specialized fauna; the species richness of Azorean endemic arthropods (including troglobionts, eutroglophiles, subtroglophiles and trogloxenes) (Send), selected because reflects the presence of unique evolutionary Azorean diversity; and the number of rare species (here equivalent to SIEs) (Srare), selected because gives some value to caves with species with very restricted distribution.

The partial indicators corresponding to the selected cave characteristics (data from IPEA database, Constância et al., 2004; Borges et al., 2008) (see Appendix 1 for more details) were selected to cover features of the caves representing their geology, threats and management: show cave (Show), that is based of a combination of cave size and diversity of scenic structures; geology (GEO), that is based on the number and uniqueness of speleothems and other geological structures; the difficulty of exploration (Dif. Expl.), that is based on a gradient of cave progression by visitors; integrity (Integrity), that is based on the pristine state of the cave; the anthropogenic threats index (Threats), that is based in a gradient of human disturbance in the epigean habitats; and accessibility (Access), that is based on how easily is the cave accessible to people.

\section{Multi-criteria index: Importance Value for Cave Conservation (IV-CC)}

If different criteria are combined to construct a single index, it is difficult to define what the single value represents (see Borges et al., 2005). Moreover, the different indices used to describe a cave value may be related. This similarity may cause a given feature to receive a higher weighting in the construction of the complex index. To avoid possible problems of collinearity, we have used partial regression analysis techniques (Legendre \& Legendre, 1998, see also Borges et al., 2005), which allow the separation of the variability of a given predictor that is independent of (i.e., not related to) the variability of another variable or set of variables. For this purpose, we applied generalized linear models (GLM) with natural logarithm link functions. In these models, the independent predictor is regressed against the potentially non-independent variable or group of variables, and the resulting residuals are retained as the independent term representing the variable. In this particular case, we have developed iterative partial regression analyses in which each iteration extracts the variability of a predictor that is independent of the formerly chosen indices. After selecting a first index (A), which is used without any transformation in the Importance Value for Cave Conservation (IV$\mathrm{CC})$ calculations, we regressed the second index (B) against $A$, obtaining its residuals $(\mathrm{rB})$. In successive steps, each index (e.g., C) is regressed against the previously included quantities (in this case, A and rB) in a multiple regression analysis to obtain its residuals (rC). The first selected index to be used without any transformation was the total number of cave-adapted endemic species $\left(\mathrm{S}_{\text {trogl. }}\right)$ because cave-adapted species 
richness was considered of major importance to cave conservation. The other indices were entered in the model according to the decreasing order of their $r^{2}$ values resulting from a GLM regression of each index with $\mathrm{S}_{\text {trogl }}$. Thus, the final IV-CC is as follows:

$\mathrm{IV}-\mathrm{CC}=\left[\left(\mathrm{S}_{\text {trogl. }} / \mathrm{S}_{\text {trogl. }} \max \right)+\left(\mathrm{RS}_{\text {end. }} / \mathrm{RS}_{\text {end. }} \max \right)\right.$ + (RShow / RShow max) + (RSrare / RSrare max $)+$ (RGEO / RGEO max) + (R 1/Dif.Expl. / R 1/Dif.Expl. max) + (RIntegrity / RIntegrity max) + (RThreats / RThreats max $)+(\mathrm{R} 1 /$ Access / R 1/Access max $)]$ / 9.

In this index, the value of the residual variance (R) of each of the additional indices for a given cave is divided by the maximum value (max) obtained within all caves. For instance, the residuals of "Show" were obtained from the polynomial model Show = $\mathrm{a}+\mathrm{b} \mathrm{S}_{\text {trogl. }}+\mathrm{c} R \mathrm{~S}_{\text {end. }}$.

We used the inverses of the indices Dif.Expl. and Access because the way in which these indices were originally built is counterintuitive. The IV-CC composite index has a maximum value of 1 (see also Borges et al., 2005).

\section{Complementarity}

An algorithm coded in Java software (available from P. Cardoso; see also Gaspar et al., 2011 for another implementation) was used to calculate the irreplaceability of each cave. We first defined targets for two different analyses by requiring that either one or two caves where a particular species occurs be represented in the datasets obtained from the analysis. The algorithm begins with a dataset including all of the caves studied. Based on the targets to be achieved, the algorithm attempts to exclude caves from this dataset at random. The selected cave is excluded from the dataset if its exclusion can occur without compromising the species targets. A new cycle with a dataset consisting of the remaining caves then begins. However, if the selected cave cannot be excluded, another cave is randomly excluded and the new dataset evaluated. This procedure was repeated until the exclusion of any cave from the dataset would prevent the species targets from being achieved. A minimum set of caves is not the only dataset determined by the algorithm. The program will also determine alternative solutions with higher numbers of caves if all of the caves selected are absolutely required to achieve the desired targets. These alternative outcomes furnish the flexibility that solutions should possess. A site found to be important but difficult or costly to preserve in a minimum solution may be replaced with two other sites in a larger solution. The program performs 10,000 iterations. From the alternative solutions found, it calculates the percentage of times that a site was selected. This percentage is the irreplaceability value for that site. The value ranges from 0 (the site is redundant in all cases) to 100 (the site is absolutely irreplaceable).

We also calculated another complementarity algorithm, the Fraction-of-Spare (Phillips et al., 2010) for all studied caves using the same targets: all troglobiont species must occur in either one or two

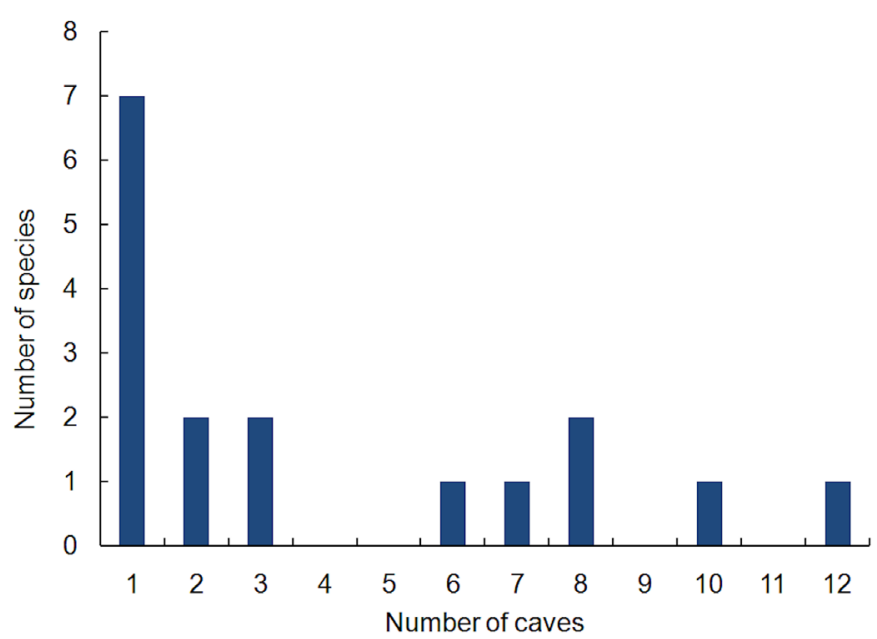

Fig. 2. Frequency distribution of Azorean troglobiont species in volcanic caves.

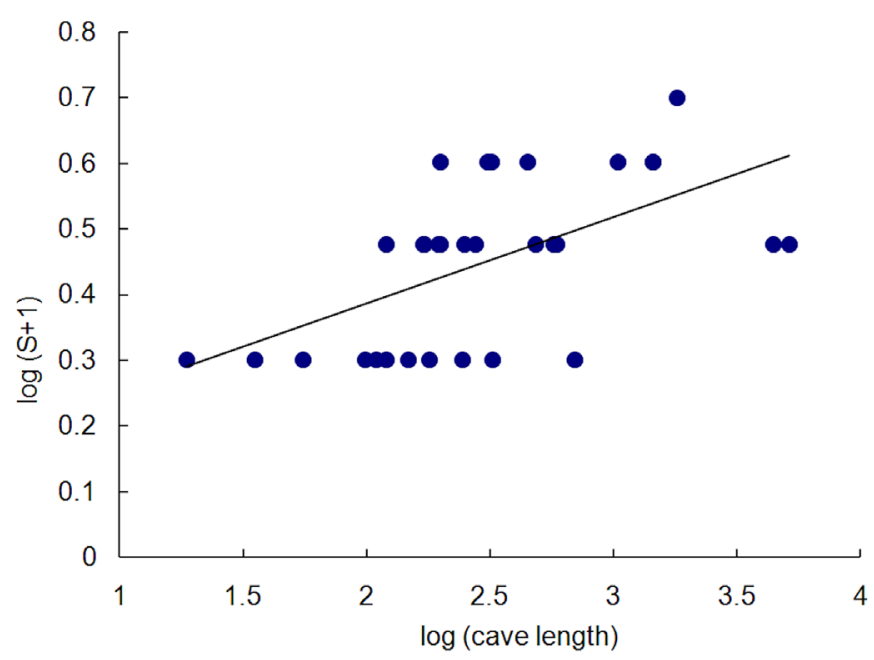

Fig. 3. Relationship between cave length (in meters) and troglobiont species richness.

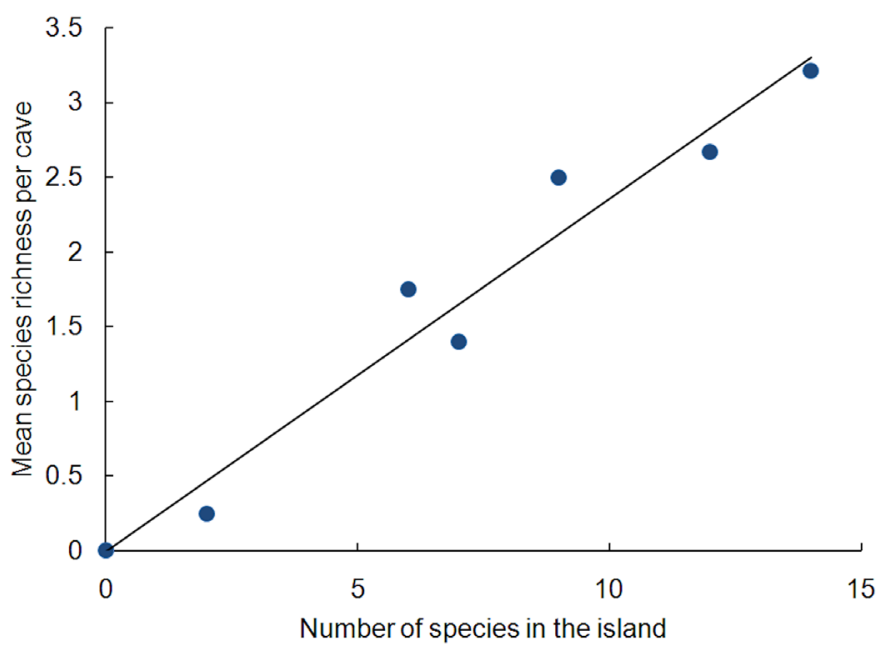

Fig. 4. Relationship between the mean local cave species richness and the regional pool of troglobiont species on each island. 
caves. This measure was calculated as a complement to irreplaceability as, even if the objectives are the same, it may present some advantages (Phillips et al., 2010). By assigning value to every site with some feature of conservation importance it does not undervalue many of such sites as usually occurs with the irreplaceability measure. It presents the additional advantage of being much less computationally intensive compared to irreplaceability, an important characteristic when dealing with large datasets. Although both summed and maximum Fraction-of-Spare may be used for conservation priorities, we used the latter so that caves with few but unique species would be highly ranked.

As stated above, the irreplaceability analyses were based on datasets for which no site could be excluded without compromising the targets. A minimum number of caves were selected in many of these datasets. Taking advantage of such algorithm, we also calculated the minimum number of sites needed to reach the different targets and determined the combinations of sites that allowed any minimum set to be reached.

\section{RESULTS}

We recorded 49 species of endemic arthropods in the 42 caves (see Appendix 2). Of these species, 17 (35\%) are troglobionts, 18 (37\%) eutroglophiles. Most troglobiont endemic species occur in few caves: a total of $61 \%$ of these species occur in at most three caves (Fig. 2). Six species are particularly widespread. The pseudoscorpion Pseudoblothrus vulcanus occurred in eight caves, the spider Rugathodes pico in seven, the centipede Lithobius obscurus azoreae in 12, the cave root-hopper Cixius azopicavus in six and the groundbeetles Trechus picoensis and T. terceiranus in eight and ten caves, respectively.

No troglobiont species were recorded in six of the caves studied. One cave has four troglobiont species (Furna dos Montanheiros, Pico island), eight have three species, 13 caves have two species and 14 caves have one species. Furna dos Montanheiros (Pico island) has eight endemic troglobionts or eutroglophiles, and five additional caves have at least six endemic troglobiont or eutroglophile species (Gruta da Agostinha, Gruta do Henrique Maciel and Gruta do Soldão on Pico island, Gruta das Agulhas and Gruta do Coelho on Terceira island).

Cave length is a predictor of troglobiont species richness (model: $\log (\mathrm{S}+1)=0.12+0.13 \log$ Area; $\mathrm{r}^{2}=$ 0.33; $\mathrm{p}=0.0007$ ) (Fig. 3).

The mean local endemic troglobiont cave species richness (alpha diversity) is a linear function of the regional number of species (gamma diversity) occurring on each island (model: local $\mathrm{S}=-0.16$ +0.33 island $\mathrm{S} ; \mathrm{r}^{2}=0.95 ; \mathrm{p}<0.001$ ) (Fig. 4). The same relationship holds for the endemic troglobiont and eutroglophile species richness (model: local $\mathrm{S}=$ $0.0063+0.24$ island $\left.\mathrm{S} ; \mathrm{r}^{2}=0.96 ; \mathrm{p}<0.001\right)$.

Table 1 shows that the ten highest-ranking caves using the multi-criteria index (IV-CC) are located on four of the six studied islands. No caves from Graciosa and Faial islands were included in the list of top-ranked caves. Pico and Terceira islands have the highest number of caves on this list. The 10 top caves include both large caves (e.g., Furna dos Montanheiros, Gruta dos Balcões, Gruta do Henrique Maciel) and small caves (e.g., Gruta do Chocolate, Furna das Cabras II). Three currently protected caves, also used as show-caves (Algar do Carvão, Gruta das Torres, Furna do Enxofre), are not included in the top 10, but Algar do Carvão (Terceira island) and Gruta das Torres (Pico island) are $11^{\text {th }}$ and $18^{\text {th }}$, respectively. Caves with an IV-CC value higher than the overall mean (0.477) occurred most frequently on Pico and Terceira islands but never occurred on Graciosa or Faial. Eight of the fourteen caves on Terceira Island are included in the ten top-ranked caves.

Completely irreplaceable caves are found on four islands (Faial, São Jorge, São Miguel and Terceira) if a target of presence in one cave per species is used. An additional island (Pico) is included if a target of presence in two caves per species is used. Many of the irreplaceable caves are located on São Jorge Island, where all of the caves studied represent the sole habitat for a number of species. Eight different combinations of 10 caves constituted the minimum datasets if the target was one representation per species (Table 2). Twenty different combinations of 15 caves constituted the minimum datasets if the target was two representations per species (Table 2).

\section{DISCUSSION}

Volcanic caves (lava-tubes and volcanic pits) are abundant on most of the Azorean islands, but with few exceptions (e.g., Algar do Carvão) these caves have received less attention from a conservation perspective than native above-ground ecosystems. Many of the caves are still pristine and harbor unique communities of invertebrates, although they are depauperated compared with the cave fauna of the neighboring Canary Islands. We found that a number of Azorean arthropod troglobionts show wide geographical distributions and are abundant (see also Amorim, 2005 and Borges et al., 2007). Cave-adapted species could disperse between cave systems through the MSS ("Milieu souterrain superficiel" or "Mesovoid Shallow Substratum" sensu Culver, 2001). This dispersal pattern characterizes Trechus terceiranus, a troglobiont species found in many lava-tubes and volcanic pits on Terceira Island (Azores) and in the MSS (Borges, 1993). However, most of the species are restricted to only one cave with no similar caves nearby and therefore lack dispersal opportunities (e.g. species in São Jorge island).

The Azorean cave arthropod fauna follows two widespread ecological patterns, the species-area curve and the proportional relationship between local and regional species richness. Longer caves tend to have more troglobiont species. This finding confirms the importance of cave length (as a surrogate of cave area) as a predictor of species diversity, which was rarely observed in cave studies (but see Silva et al., 2011). The low $r^{2}$ observed is due to the fact that other variables not taken into account in this study are also explaining the observed number of species. Islands with more troglobiont and eutroglophile species tend to have more species per cave on average. This result 
Table 2. Irreplaceability, fraction of spare and caves included in the minimum datasets with two different targets: troglobiont species represented in at least one or two caves. For the minimum datasets, $X$ represents caves that are part of all minimum datasets and other letters represent groups of caves that may be replaced by each other; numbers after letters represent how many caves must be included from the group so that the minimum dataset is reached.

\begin{tabular}{|c|c|c|c|c|c|c|c|}
\hline Site & Island & Irreplaceability & Irreplaceability & $\begin{array}{l}\text { Fraction } \\
\text { of Spare }\end{array}$ & $\begin{array}{l}\text { Fraction } \\
\text { of Spare }\end{array}$ & $\begin{array}{c}\text { Minimum } \\
\text { dataset }\end{array}$ & $\begin{array}{r}\text { Minimum } \\
\text { dataset }\end{array}$ \\
\hline & & Target 1 & Target 2 & Target 1 & Target 2 & Target 1 & Target 2 \\
\hline Gruta do Parque do Capelo & Faial & 1 & 1 & 1 & 1 & $x$ & $x$ \\
\hline Algar das Bocas do Fogo & São Jorge & 1 & 1 & 1 & 1 & $x$ & $x$ \\
\hline Algar do Morro Pelado & São Jorge & 1 & 1 & 1 & 1 & $x$ & $x$ \\
\hline Gruta da Beira & São Jorge & 1 & 1 & 1 & 1 & $x$ & $x$ \\
\hline Gruta de Água de Pau & São Miguel & 1 & 1 & 1 & 1 & $x$ & $x$ \\
\hline Gruta das Agulhas & Terceira & 1 & 1 & 1 & 1 & $x$ & $x$ \\
\hline Gruta das Anelares & Faial & 0.5075 & 1 & 1 & 1 & $A(1)$ & $x$ \\
\hline Furnas das Cabras II (terra) & Pico & 0.5044 & 1 & 1 & 1 & $B(1)$ & $x$ \\
\hline Gruta da Ribeira do Fundo & Pico & 0.4956 & 1 & 1 & 1 & $\mathrm{~B}(1)$ & $x$ \\
\hline Gruta do Cabeço do Canto & Faial & 0.4925 & 1 & 1 & 1 & $A(1)$ & $x$ \\
\hline Furna dos Montanheiros & Pico & 0.3794 & 0.7023 & 0.5 & 1 & $x$ & $x$ \\
\hline Algar do Carvão & Terceira & 0.3383 & 0.6674 & 0.5 & 1 & $C(1)$ & $A(2)$ \\
\hline Gruta de Santa Maria & Terceira & 0.3361 & 0.6653 & 0.5 & 1 & $C(1)$ & $A(2)$ \\
\hline Gruta da Malha & Terceira & 0.3256 & 0.6673 & 0.5 & 1 & $C(1)$ & $A(2)$ \\
\hline Gruta dos Vimes & Pico & 0.3117 & 0.6491 & 0.5 & 1 & & $B(1)$ \\
\hline Furna de Frei Matias & Pico & 0.3089 & 0.6486 & 0.5 & 1 & & $\mathrm{~B}(1)$ \\
\hline Gruta da Agostinha & Pico & 0.1536 & 0.2876 & 0.2 & 0.25 & & $C(1)$ \\
\hline Gruta do Soldão & Pico & 0.1532 & 0.2926 & 0.2 & 0.25 & & $C(1)$ \\
\hline Gruta do Mistério da Silveira I & Pico & 0.1383 & 0.278 & 0.2 & 0.25 & & $C(1)$ \\
\hline Gruta das Canárias & Pico & 0.1364 & 0.2778 & 0.2 & 0.25 & & $C(1)$ \\
\hline Gruta das Torres & Pico & 0.0601 & 0.1617 & 0.2 & 0.25 & & \\
\hline Furna Ruim & Faial & 0.054 & 0.0941 & 0.166667 & 0.2 & & \\
\hline Gruta do Henrique Maciel & Pico & 0.0511 & 0.0888 & 0.166667 & 0.2 & & \\
\hline Gruta dos Balcões & Terceira & 0.0252 & 0.0128 & 0.111111 & 0.125 & & \\
\hline Galeria do Forninho & Graciosa & 0.0249 & 0.0156 & 0.090909 & 0.1 & & \\
\hline Gruta dos Buracos & Terceira & 0.0243 & 0.0139 & 0.090909 & 0.1 & & \\
\hline Gruta da Branca Opala & Terceira & 0.0229 & 0.0173 & 0.090909 & 0.1 & & \\
\hline Gruta da Achada & Terceira & 0.0224 & 0.016 & 0.111111 & 0.125 & & \\
\hline Gruta da Madre de Deus & Terceira & 0.0223 & 0.0151 & 0.090909 & 0.1 & & \\
\hline Furna da Baliza & Pico & 0 & 0 & 0.142857 & 0.166667 & & \\
\hline Furna Nova I & Pico & 0 & 0 & 0.142857 & 0.166667 & & \\
\hline Gruta do Caldeira & Terceira & 0 & 0 & 0.111111 & 0.125 & & \\
\hline Gruta do Chocolate & Terceira & 0 & 0 & 0.111111 & 0.125 & & \\
\hline Gruta do Coelho & Terceira & 0 & 0 & 0.142857 & 0.166667 & & \\
\hline Gruta do Natal & Terceira & 0 & 0 & 0.111111 & 0.125 & & \\
\hline Gruta dos Principiantes & Terceira & 0 & 0 & 0.142857 & 0.166667 & & \\
\hline
\end{tabular}


implies that there is no signal of local community saturation of species at the cave scale and that overall island regional diversity is an effective predictor of local cave diversity. Moreover, our results confirm the predictions of empirical studies suggesting that the size of most local cave species assemblages is proportional to the size of the regional pool of potential colonists (Malard et al., 2009; see review for epigean fauna in Srivastava, 1999).

The current study is novel because we combined cave biological, geological and management characteristics in a multi-criteria index, the Importance Value for Cave Conservation (IV-CC) composite index first proposed by Borges et al. (2005) for epigean forest arthropods using only biological data. The strategy followed allows biological data to be combined with geodiversity and other cave information to better predict the conservation value of caves. The results obtained indicate that the caves of Terceira and Pico islands may be considered conservation hotspots at the scale of the Azores. These islands also have the greatest numbers of caves, and most of the efforts at conservation management should therefore be directed at Terceira and Pico islands. However, the restricted distribution of the single-island endemics occurring in the caves of the islands of São Miguel, São Jorge and Faial implies that strict conservation management measures should also be applied to the caves listed in the minimum complementary set of caves (Table 2). In fact, this conservation exercise highlights the importance of São Jorge Island, where all of the caves studied represent the sole habitat for unique single-island endemics, one species per cave (Algar do Morro Pelado, Algar das Bocas do Fogo and Gruta da Beira).

In all, 36 caves have at least one troglobiont species. However, the protection of only 10 caves is needed to conserve the 17 troglobiont species in at least one cave. Eight different combinations of 10 caves constituted the minimum datasets if the target was one representation per species (Table 2). A close look at those caves shows that three highly relevant caves are not included in the-top ranked caves based on the IV-CC. These three caves are Gruta da Beira (São Jorge island), Gruta das Anelares and Gruta do Parque do Capelo (Faial island). These caves are small. The major threats to their conservation include land use changes (pasture intensification) that tend to produce an impermeable cave roof and to compact the cave floor (e.g., Gruta da Beira, S. Jorge island); pollution (e.g., sewage or waste disposal); the introduction of exotic plants and/or animals; and disturbance by human visitation. Unfortunately, these processes also threaten most of the top-ranked caves listed simultaneously in Tables 1 and 2. Human visitation to the show-caves (Algar do Carvão, Gruta do Natal, Furna do Enxofre, Gruta das Torres and Gruta do Carvão) has certain negative impacts, particularly in Algar do Carvão and Gruta do Carvão, which have long periods of visitation during the year. In Algar do Carvão, the intensive show-cave activity is markedly impacting the temperature and relative humidity of the cave. These changes have already produced visual impacts through the spread of green algae in the speleothems (see http://gigapan.org/ gigapans $/ 83300 /$ ) and the decreasing activity density of the ground-beetle Trechus terceiranus as measured using replacement-trapping techniques (Cardoso et al., subm.; P.A.V. Borges et al., unpublished data). The case of Gruta das Torres (Pico island) is less problematic because only a small part of the cave is open to the public and visitors use only portable lights.

Interestingly, the minimum dataset of caves needed to conserve the 17 troglobiont species at least once (target 1) (Table 2) does not include certain caves whose numbers of troglobionts and eutroglophiles make the caves biodiversity hotspots: Gruta do Henrique Maciel (Pico island) and Gruta do Coelho (Terceira island). However, this finding does not mean that these caves have less importance. These caves are needed as members of a network of caves that could adequately reinforce the conservation of cave animals on Terceira and Pico islands. In fact, because many caves are isolated entities they lack the "rescue effect": only "source" populations can be maintained in ecological and evolutionary time (Rosenzweig, 1995). This disagreement highlights the importance of using complementary information on conservation strategies.

The application of correct management measures urgently requires attention. Certain steps in this direction are already being taken by the Azorean Government through the preparation of new legislation, but willingness of enforcement is another matter all together. In fact, the dynamics and interactive nature of the epigean habitat matrix imply the need for certain cautionary strategies. The economically important pastures that support the production of dairy products generate substantial impacts in the aboveground catchment areas surrounding the caves. Both this factor and tourism will imply a continuous decrease in the quality of Azorean cave ecosystems. With the exception of Algar do Carvão (Borges \& Pereira, unpublished data) and certain additional caves in Terceira and Pico (Amorim \& Pereira, unpublished data), no monitoring of troglobiont populations is conducted in the Azores. Accordingly, few reliable data will be available for current IUCN red listing strategies (but see Cardoso et al., 2011a).

Important research was performed on Azorean cave biodiversity in the past two decades, but further taxonomic and ecological work is also needed because many unknown species may remain unrecorded and because other overlooked habitats need further investigation (e.g., MSS on older islands). The direct dependency of cave animals on a stable high relative humidity also implies the need for certain mitigation measures in Azorean show-caves.

Although the ranking obtained using IV-CC incorporates a wide range of cave characteristics (biological, geological, management), the inclusion of genetic diversity measures (Amorim, 2005; Amorim et al., unpublished data) may further improve the conservation value of the IV-CC multi-criteria index presented here. Another possibility would be the study of phylogenetic diversity and differentiation between caves. Future research in this area could help to 
improve the currently proposed conservation priorities. Overall, given the multi-criteria IV-CC and the robust complementarity measures developed by our study, we strongly propose the use of our methodology to define future cave priority management strategies in the Azores. It is possible that our methodology can also be used elsewhere for this purpose.

\section{ACKNOWLEDGEMENTS}

The data collected in the Azores and analyzed in this study result from the cumulative effort of many colleagues during the past twenty years and more recently from the FCT's Project PTDC/ AMB/70801/2006 - Understanding Underground Biodiversity: Studies of Azorean Lava Tubes. (20092011). PC and IRA were supported by the Portuguese Foundation for Science and Technology SFRH/ BPD/40688/2007 and SFRH/BPD/29578/2006, respectively.

\section{REFERENCES}

Amorim I.R., 2005 - Colonization and diversification on oceanic islands: forest Tarphius and cave dwelling Trechus beetles of the Azores. Ph.D. dissertation, Department of Ecology and Evolutionary Biology, University of California, Los Angeles, 282 pp.

Barr T.C. \& Holsinger J.R., 1985 - Speciation in cave faunas. Annual Review of Ecology and Systematics, 16: 313-317.

http://dx.doi.org/10.1146/annurev.es.16.110185.001525

Borges P.A.V., 1993 - First records for the mesocavernous shallow stratum (M.S.S.) from the Azores. Mémoires de Biospéologie, 20: 49-54.

Borges P.A.V., Azevedo E.B., Borba A., Dinis F.O., Gabriel R. \& Silva E., 2009 - Ilhas Oceânicas. In: Pereira H.M., Domingos T. \& Vicente L. (Eds.), Portugal Millenium Ecosystem Assessment. Lisboa: Escolar Editora: 461-508.

Borges P.A.V., Aguiar C., Amaral J., Amorim I.R., André G., Arraiol A., Baz A., Dinis F., Enghoff H., Gaspar C., Ilharco F., Mahnert V., Melo C., Pereira F., Quartau J.A., Ribeiro S., Ribes J., Serrano A.R.M., Sousa A.B., Strassen R.Z., Vieira L., Vieira V., Vitorino A. \& Wunderlich J., 2005 - Ranking protected areas in the Azores using standardized sampling of soil epigean arthropods. Biodiversity and Conservation, 14: 2029-2060. http://dx.doi.org/10.1007/s10531-004-4283-y

Borges P.A.V. \& Oromí P., 1994 - The Azores, In: Juberthie, C. \& Decu, V. (Eds.), Encyclopaedia Biospeologica. Moulis: Sociétè de Biospéologie, I: 605-610.

Borges P.A.V., Oromí P., Serrano A.R.M., Amorim I.R. \& Pereira P., 2007 - Biodiversity patterns of cavernicolous ground-beetles and their conservation status in the Azores, with the description of a new species: Trechus isabelae $n$. sp. (Coleoptera: Carabidae: Trechinae). Zootaxa, 1478: 21-31.

Borges P.A.V., Pereira F. \& Constância J.P., 2008 - Indicators of conservation value of Azorean caves based on its arthropod fauna. Proceedings of the X, XI and XII International Symposia on Vulcanospeleology: 109-113.
Borges P.A.V., Serrano A.R.M. \& Amorim I.R., 2004 New species of cave-dwelling beetles (Coleoptera: Carabidae: Trechinae) from the Azores. Journal of Natural History, 38: 1303- 1313.

http://dx.doi.org/10.1080/0022293031000155214

Borges P.A.V., Vieira V., Amorim I.R., Bicudo N., Fritzén N., Gaspar C., Heleno R., Hortal J., Lissner J., Logunov D., Machado A., Marcelino J., Meijer S.S., Melo C., Mendonça E.P., Moniz J., Pereira F., Santos A.S., Simões A.M. \& Torrão E., 2010 - List of arthropods (Arthropoda). In: Borges P.A.V., Costa A., Cunha R., Gabriel R., Gonçalves V., Martins A.F., Melo I, Parente M., Raposeiro P., Rodrigues P., Santos R.S., Silva L., Vieira P. \& Vieira V. (Eds.) A list of the terrestrial and marine biota from the Azores. Cascais: Princípia: 179-246.

Cardoso P., 2011 - Habitats Directive species lists: urgent need of revision. Insect Conservation and Diversity, DOI:10.1111/j.1752-4598.2011.00140.x

Cardoso P., Borges P.A.V., Triantis K., Ferrández M.A. \& Martín J.L., 2011a - Adapting the IUCN Red List criteria for invertebrates. Biological Conservation, 144: 2432-2440.

http://dx.doi.org/10.1016/j.biocon.2011.06.020

Cardoso P., Erwin T.L., Borges P.A.V. \& New T.R., $2011 \mathrm{~b}$ - The seven impediments in invertebrate conservation and how to overcome them. Biological Conservation, 144: 2647-2655.

http://dx.doi.org/10.1016/j.biocon.2011.07.024

Cardoso P., Amorim I.R., Hedin M., Pereira F. \& Borges P.A.V., subm. - Global warming as an extinction driver of cave obligate species. Global Change Biology.

Christman M.C. \& Culver D.C., 2001 - The relationship between cave biodiversity and available habitat. Journal of Biogeography, 28: 367-380. http://dx.doi.org/10.1046/j.1365-2699.2001.00549.x

Christman M.C., Culver D.C., Madden M.K. \& White D., 2005 - Patterns of endemism of the eastern North American cave fauna. Journal of Biogeography, 32: 1441-1452.

http://dx.doi.org/10.1111/j.1365-2699.2005.01263.x

Constância J.P., Borges P.A.V., Costa M.P., Nunes J.C., Barcelos P., Pereira F. \& Braga, T., 2004 Ranking Azorean caves based on management indices. Abstract book of the XIth International Symposium on Vulcanospeleology (Pico, Açores).

Culver D.C., 2001 - Subterranean ecosystems. In: Levin S.A. (Ed.), Encyclopaedia of Biodiversity. Academic Press, 5: 527-540.

Culver D.C. \& Pipan T., 2009 - Biology of caves and other subterranean habitats. Oxford University Press, Oxford: 256 p.

Ferrier S., Pressey R.L. \& Barrett T.W., 2000 - A new predictor of the irreplaceability of areas for achieving a conservation goal, its application to realworld planning, and a research agenda for further refinement. Biological Conservation, 93: 303-325. http://dx.doi.org/10.1016/S0006-3207(99)00149-4

Gaspar C., Gaston K.J., Borges P.A.V. \& Cardoso P., 2011 - Selection of priority areas for arthropod conservation in the Azores archipelago. Journal of Insect Conservation, 15: 671-684. http://dx.doi.org/10.1007/s10841-010-9365-4 
Legendre P. \& Legendre L., 1998 - Numerical Ecology, Second English edn. Elsevier, Amsterdam.

Malard F., Boutin C., Camacho A.I., Ferreira D., Michel G., Sket B. \& Stoch F., 2009 - Diversity patterns of stygobiotic crustaceans across multiple spatial scales in Europe. Freshwater Biology, 54: 756-776.

http://dx.doi.org/10.1111/j.1365-2427.2009.02180.x

Martín J.L., Cardoso P., Arechavaleta M., Borges P.A.V, Faria B.F., Abreu C., Aguiar A.F., Carvalho J.A., Costa A.C., Cunha R.T., Gabriel R., Jardim R., Lobo C., Martins A.M.F., Oliveira P., Rodrigues P., Silva L., Teixeira D., Amorim I.R., Fernandes F., Homem N., Martins B., Martins M. \& Mendonça, E., 2010 - Using taxonomically unbiased criteria to prioritize resource allocation for oceanic island species conservation. Biodiversity and Conservation, 19: 1659-1682. http://dx.doi.org/10.1007/s10531-010-9795-Z

Nunes J.C., 1999 - A actividade vulcânica na ilha do Pico do Plistocénico Superior ao Holocénico: mecanismo eruptivo e Hazard vulcânico. Ph.D Thesis, Universidade dos Açores, Ponta Delgada.

Oromí P., 2004 - Canary Islands: Biospeleology. In: Gunn, J. (Ed.), Encyclopedia of Caves and Karst Science. New York: Fitzroy Dearborn: 179-181.

Oromí P. \& Martín J.L., 1992 - The Canary Islands. Subterranean fauna: characterization and composition. In: Camacho, A.I. (Ed.), The Natural History of Biospeleology. Madrid: C.S.I.: 527-568.

Oromí P., Martín J.L., Ashmole, N.P. \& Ashmole M.J., 1990 - A preliminary report on the cavernicolous fauna of the Azores. Mémoires de Biospéologie, 17: 97-105.

Oromí P. \& Izquierdo I., 1994 - Canary Islands. In: Juberthie, C. \& Decu, V. (Eds.), Encyclopaedia Biospeologica. Moulis: Société de Biospéologie, 1: 631-639.

Pereira F., Borges P.A.V., Costa M.P., Constância J.P., Nunes J.C., Barcelos P. Braga T., Gabriel R., Amorim I.R., in prep. - Catalogue of the Azorean caves (lava tube caves, volcanic pits, and seaerosion caves). Secretaria Regional do Ambiente e dos Mar, GESPEA, Horta, 320 pp.
Phillips S.J., Archer A., Pressey R.L., Torkornoo D., Applegate D., Johnson D. \& Watts M.E., 2010 Voting power and target-based site prioritization. Biological Conservation, 143: 1989-1997. http://dx.doi.org/10.1016/j.biocon.2010.04.051

Pressey R.L., Johnson I.R. \& Wilson P.D., 1994 Shades of irreplaceability: towards a measure of the contribution of sites to a reservation goal. Biodiversity and Conservation, 3: 242-262. http://dx.doi.org/10.1007/BF00055941

Reboleira A.S.P.S., Borges P.A.V., Gonçalves F., Serrano A.R.M. \& Oromí P., 2011 - The subterranean fauna of a biodiversity hotspot region - Portugal: an overview and its conservation. International Journal of Speleology, 40: 23-37. http://dx.doi.org/10.5038/1827-806X.40.1.4

Ricklefs R.E., 1987 - Community Diversity: Relative Roles of Local and Regional Processes. Science, 235: $167-171$.

http://dx.doi.org/10.1126/science.235.4785.167

Rosenzweig M.L., 1995 - Species diversity in space and time. Cambridge University Press, Cambridge, $436 \mathrm{p}$.

http://dx.doi.org/10.1017/CBO9780511623387

Serrano A.R.M. \& Borges P.A.V., 2010 - The caveadapted arthropod fauna from Madeira archipelago. Arquipélago Life and Marine Sciences, 27: 1-7.

Sket B., 2008 - Can we agree on an ecological classification of subterranean animals? Journal of Natural History, 42: 1549-1563.

http://dx.doi.org/10.1080/00222930801995762

Silva M..S., Martins R.P. \& Ferreira R. L., 2011 Cave lithology determining the structure of the invertebrate communities in the Brazilian Atlantic Rain Forest. Biodiversity and Conservation, 20: 1713-1729.

http://dx.doi.org/10.1007/s10531-011-0057-5

Srivastava D.S., 1999 - Using local-regional richness plots to test for species saturation: pitfalls and potentials. Journal of Animal Ecology, 68: 1-16. http://dx.doi.org/10.1046/j.1365-2656.1999.00266.x

Whitten T., 2009 - Applying ecology for cave management in China and neighbouring countries. Journal of Applied Ecology, 46: 520-523. http://dx.doi.org/10.1111/j.1365-2664.2009.01630.x 
Appendix 1. List of indicators selected to describe geology, threat and management features of the caves (adapted from Constância et al., 2004)

\begin{tabular}{|c|c|c|c|}
\hline Code & Indicator & & Explanation \\
\hline \multirow[t]{6}{*}{ Show } & Show cave & 0 & No information available \\
\hline & & 1 & Small cave (less than de $100 \mathrm{~m}$ length $\times 2 \mathrm{~m}$ height) \\
\hline & & 2 & Small and simple cave with at least $100 \mathrm{~m}$ and less than $200 \mathrm{~m}$ \\
\hline & & 3 & Size between 200 and $500 \mathrm{~m}$ but few interesting structures \\
\hline & & 4 & Large caves (more than $500 \mathrm{~m}$ ) and with diversity of structures \\
\hline & & 5 & Very large caves (more than $1000 \mathrm{~m}$ ) and with diversity of structures \\
\hline \multirow[t]{6}{*}{ GEO } & Geology & 0 & No information available \\
\hline & & 1 & Absence of relevant geological structures \\
\hline & & 2 & Presence of very common geological structures (e.g. lava stalactites) \\
\hline & & 3 & Presence of common geological structures (e.g. benches, striated walls) \\
\hline & & 4 & $\begin{array}{l}\text { Presence of rare geological structures (e.g. secondary deposits, levees, } \\
\text { multiple levels of lava tubes, etc.) }\end{array}$ \\
\hline & & 5 & $\begin{array}{l}\text { Presence of very rare geological structures (e.g. gas bubbles, stalagmite, } \\
\text { columns) }\end{array}$ \\
\hline \multirow[t]{6}{*}{ Dif.Expl. } & Difficulty of & 0 & No information available \\
\hline & Exploration & 1 & Lava tube or pit of difficult exploration due to difficulty of progression \\
\hline & & 2 & $\begin{array}{l}\text { Lava tube or pit of difficult exploration in some parts due to difficulty of pro- } \\
\text { gression }\end{array}$ \\
\hline & & 3 & Cavity with some obstacles \\
\hline & & 4 & Some obstacles present but easy to transpose \\
\hline & & 5 & Very easy exploration - all people could visit the cave \\
\hline \multirow[t]{6}{*}{ Integrity } & Integrity & 0 & No information available \\
\hline & & 1 & More than $50 \%$ of the cave destroyed \\
\hline & & 2 & Some evidences of destruction ( $<50 \%$ of the cave's length) \\
\hline & & 3 & More than $90 \%$ of the cave's length well preserved but Human disturbance \\
\hline & & 4 & Well preserved cave and few signs of Human disturbance \\
\hline & & 5 & Very well cave preserved \\
\hline \multirow[t]{6}{*}{ Threats } & Anthropogenic Threat & 0 & No information available \\
\hline & & 1 & Partially destroyed cave due to epigean Human disturbance \\
\hline & & 2 & Identified epigean Human activities that could cause near-future disturbance \\
\hline & & 3 & Identified epigean Human activities that could cause future disturbance \\
\hline & & 4 & Identified epigean Human activities that present no potential threat \\
\hline & & 5 & No Human activities or threats in the area of the cave \\
\hline \multirow[t]{6}{*}{ Access } & Accessibility & 0 & No information available \\
\hline & & 1 & Very difficult to access - no roads or tracks available \\
\hline & & 2 & Difficult access - no near locality and more than $45 \mathrm{~m}$ walk \\
\hline & & 3 & Difficult access - no near locality or property owner needs to grant access \\
\hline & & 4 & Easy access, with available public transport \\
\hline & & 5 & Easy access, easy to locate, near a locality \\
\hline
\end{tabular}


Appendix 2. List of endemic arthropods present in the 42 caves of the Azores. Adaptation: T - troglobionts; E - eutroglophiles; S - subtroglophiles; $\mathrm{Tr}$ - trogloxenes.

\begin{tabular}{|c|c|c|c|c|}
\hline Classe & Order & Family & Species & Adaptation \\
\hline Arachnida & Pseudoscorpiones & Syarinidae & Microcreagrella caeca caeca (Simon, 1883) & $E$ \\
\hline Arachnida & Pseudoscorpiones & Syarinidae & Pseudoblothrus oromii Mahnert,1990 & $\mathrm{T}$ \\
\hline Arachnida & Pseudoscorpiones & Syarinidae & Pseudoblothrus vulcanus Mahnert, 1990 & $\mathrm{~T}$ \\
\hline Arachnida & Oribatida & Cepheidae & Tritegeus (n. sp.) Morell \& Subías & E \\
\hline Arachnida & Oribatida & Damaeidae & Damaeus pomboi Pérez-Íñigo, 1987 & $E$ \\
\hline Arachnida & Oribatida & Galumnidae & Galumna sp. (n sp.) Morell \& Subías & $E$ \\
\hline Arachnida & Oribatida & Galumnidae & Vaghia sp. (n sp.) Morell \& Subías & $\mathrm{E}$ \\
\hline Arachnida & Oribatida & Hermanniellidae & Hermanniella sp. 1 (n sp.) Morell \& Subías & E \\
\hline Arachnida & Oribatida & Hermanniellidae & Hermanniella sp. 2 (n.sp) Morell \& Subías & $E$ \\
\hline Arachnida & Oribatida & Liacaridae & Liacarus angustatus (Weigmann, 1976) & $E$ \\
\hline Arachnida & Oribatida & Nothridae & Nothrus palustris azorensis Pérez-Íñigo, 1897 & E \\
\hline Arachnida & Oribatida & Phthiracaridae & $\begin{array}{l}\text { Hoplophthiracarus maritimus (Pérez-Íñigon \& } \\
\text { Pérez-Íñigo Jr., 1996) }\end{array}$ & $E$ \\
\hline Arachnida & Oribatida & Phthiracaridae & Phthiracarus falciformis Morell \& Subías, 1991 & $E$ \\
\hline Arachnida & Araneae & Araneidae & Gibbaranea occidentalis Wunderlich, 1989 & S \\
\hline Arachnida & Araneae & Linyphiidae & Lepthyphantes acoreensis Wunderlich, 1992 & $S$ \\
\hline Arachnida & Araneae & Linyphiidae & Porrhomma borgesi Wunderlich, 2008 & $S$ \\
\hline Arachnida & Araneae & Linyphiidae & Turinyphia cavernicola Wunderlich, 2008 & $\mathrm{~T}$ \\
\hline Arachnida & Araneae & Lycosidae & Pardosa acorensis Simon, 1883 & $\operatorname{Tr}$ \\
\hline Arachnida & Araneae & Theridiidae & Rugathodes acoreensis Wunderlich, 1992 & $S$ \\
\hline Arachnida & Araneae & Theridiidae & Rugathodes pico (Merrett \& Ashmole, 1989) & $\mathrm{T}$ \\
\hline Malacostraca & Amphipoda & Talitridae & Macarorchestia martini Stock, 1989 & $\mathrm{~T}$ \\
\hline Malacostraca & Amphipoda & Talitridae & Orchestia chevreuxi De Guerne, 1887 & S \\
\hline Malacostraca & Isopoda & Philosciidae & Chaetophiloscia guernei (Dollfus, 1887) & E \\
\hline Malacostraca & Isopoda & Trichoniscidae & Gen.nov. sp. nov. & $\mathrm{T}$ \\
\hline Chilopoda & Lithobiomorpha & Lithobiidae & Lithobius melanops borgei Eason \& Ashmole, 1992 & $E$ \\
\hline Chilopoda & Lithobiomorpha & Lithobiidae & Lithobius obscurus azoreae Eason \& Ashmole, 1992 & $\mathrm{~T}$ \\
\hline Collembola & Poduromorpha & Onychiuridae & Onychiurus n. sp. Gama & E \\
\hline Collembola & Entomobryomorpha & Entomobryidae & Pseudosinella ashmoleorum Gama, 1988 & $E$ \\
\hline Collembola & Entomobryomorpha & Entomobryidae & Pseudosinella azorica Gama, 1988 & $\mathrm{E}$ \\
\hline Insecta & Hemiptera & Cixiidae & Cixius azopicavus Hoch, 1991 & $\mathrm{~T}$ \\
\hline Insecta & Hemiptera & Cixiidae & Cixius azopifajo azopifajo Remane \& Asche, 1979 & $S$ \\
\hline Insecta & Hemiptera & Cixiidae & Cixius azoterceirae Remane \& Asche, 1979 & S \\
\hline Insecta & Hemiptera & Cixiidae & Cixius cavazoricus Hoch, 1991 & $\mathrm{~T}$ \\
\hline Insecta & Coleoptera & Carabidae & Bembidion schmidti mequignoni Colas, 1939 & $\operatorname{Tr}$ \\
\hline Insecta & Coleoptera & Carabidae & Thalassophilus azoricus Oromí \& Borges, 1991 & $\mathrm{~T}$ \\
\hline Insecta & Coleoptera & Carabidae & Trechus isabelae Borges \& Serrano, 2007 & $\mathrm{~T}$ \\
\hline Insecta & Coleoptera & Carabidae & Trechus jorgensis Oromí \& Borges, 1991 & $\mathrm{~T}$ \\
\hline Insecta & Coleoptera & Carabidae & Trechus montanheirorum Oromí \& Borges, 1991 & $\mathrm{~T}$ \\
\hline Insecta & Coleoptera & Carabidae & Trechus oromii Borges, Serrano \& Amorim, 2004 & $\mathrm{~T}$ \\
\hline Insecta & Coleoptera & Carabidae & Trechus pereirai Borges, Serrano \& Amorim, 2004 & $\mathrm{~T}$ \\
\hline Insecta & Coleoptera & Carabidae & Trechus picoensis Machado, 1988 & $\mathrm{~T}$ \\
\hline Insecta & Coleoptera & Carabidae & Trechus terceiranus Machado, 1988 & $\mathrm{~T}$ \\
\hline Insecta & Coleoptera & Curculionidae & Drouetius azoricus azoricus (Drouet, 1859) & $\operatorname{Tr}$ \\
\hline Insecta & Coleoptera & Curculionidae & Drouetius borgesi centralis Machado, 2009 & $\operatorname{Tr}$ \\
\hline Insecta & Coleoptera & Dystiscidae & Hydroporus guernei Régimbart, 1891 & $\operatorname{Tr}$ \\
\hline Insecta & Coleoptera & Zopheridae & Tarphius tornvalli Gillerfors, 1985 & $\operatorname{Tr}$ \\
\hline Insecta & Lepidoptera & Yponomeutidae & Argyresthia atlanticella Rebel, 1940 & $\operatorname{Tr}$ \\
\hline Insecta & Diptera & Phoridae & Megaselia leptofemur Disney, 2007 & $\mathrm{E}$ \\
\hline Insecta & Diptera & Phoridae & Megaselia miguelensis Disney, 2007 & $E$ \\
\hline
\end{tabular}

